\title{
EFEKTIFITAS PEMBERIAN KOMPOS TRICHODERMA TERHADAP PERTUMBUHAN DAN PRODUKSI RUMPUT Brachiaria humidicola DI LAHAN GAMBUT
}

\section{(Effectivity of Trichoderma Compost to the Growth and Production Brahiaria humidicola on Peat Land)}

Maria Erviana Kusuma, Kastalani, Kristina

Program Studi Peternakan, Universitas Kristen Palangka Raya

Palangka Raya, Indonesia

email kusumamariaerviana@gmail.com

Article Submitted : 17-12-2018

Article Accepted : 14-01-2019

\begin{abstract}
The aims of this study is to determine the effect of giving Trichoderma Compost on the growth and production of Brachiaria humidicola grass on peatlands and to determine the dosage of Trichoderma compost which gives the best results for the growth and production of Brachiaria humidicola grass on peatlands. This research was conducted in Tanjung Taruna Village, Jabiren Raya District, Pulang Pisau Regency, from September to November 2018. This study was designed using a Completely Randomized Design (CRD) with a single treatment of various doses of compost $(\mathrm{K}), \mathrm{k} 0=$ without compost, $\mathrm{k} 1=20$ tons ha $\mathrm{h}^{-1}, \mathrm{k} 2=30$ tons ha $^{-1}$ and $\mathrm{k} 3=40$ tons $\mathrm{ha}^{-1}$. The results of this study showed that giving compost had an effect on the plant height of Brahiaria humidicola grass 6 week after planting and 8 week after planting as well as crop production and 30 ton ha ${ }^{-1}$ compost giving the best production of Brahiaria humidicola on peat land.
\end{abstract}

Key words : Compost Trichoderma, growth, production, peat land

\section{PENDAHULUAN}

Hijauan makanan ternak merupakan sumber bahan makanan utama yang sangat dibutuhkan oleh ternak ruminansia terutama untuk hidup, berproduksi dan berkembang biak. Oleh sebab itu dalam usaha peternakan ketersediaan hijauan makanan ternak dirasakan sangat penting peningkatannya baik secara kualitas maupun kuantitas, karena 74 sampai $94 \%$ dari total ransum adalah hijauan makanan ternak. Sebagai bahan makanan utama ternak ruminansia, maka ketersediaannya pun haruslah secara kontinyu, baik dari jenis rerumputan maupun leguminosa.

Salah satu faktor produksi yang sangat menentukan keberhasilan produksi ternak adalah ketersediaan hijauan. Peningkatan populasi ternak akan menyebabkan kesulitan dalam penyediaan hijauan pakan ternak. Untuk meningkatkan ketersediaan hijauan makanan ternak telah dikembangkan berbagai macam rumput unggul yang mempunyai tingkat produksi tinggi dan disukai oleh ternak serta mudah dalam pengembangannya, salah satu diantarnya adalah rumput Brachiaria humidicola.

Jenis rumput Brachiaria humidicola merupakan hijauan palatabel yang dapat digunakan sebagai rumput potongan dan rumput penggembalaan. Rumput ini mempunyai kemampuan menekan pertumbuhan gulma, adaptif terhadap 
pengairan kurang baik, toleran terhadap penggembalaan berat sehingga mempunyai peranan yang yang cukup besar bagi pengembangan dan penyediaan hijauan di daerah tropik. Namun demikian produksi rumput ini akan menjadi baik apabila ditanam pada lahan yang mengandung nutrisi atau unsur hara yang cukup tersedia secara terus menerus.

Pada lahan gambut jenis rumput ini juga dapat tumbuh dan berproduksi. Namun tingkat pertumbuhan dan produksinya tidak sebaik bila rumput tersebut ditanam pada jenis tanah mineral. Hal ini disebabkan karena lahan gambut masih mempunyai sifat lahan yang mempunyai tingkat kesuburan yang rendah, disamping mempunyai tingkat kemasaman yang rendah sehingga akan mempengaruhi pola pertumbuhan tanaman dan pada akhirnya akan berpengaruh terhadap tingkat produktivitas.

Gambut merupakan sumberdaya alam yang secara potensial tersedia dimanfaatkan untuk peningkatan produksi tanaman. Provinsi Kalimantan Tengah umumnya adalah gambut dengan berbagai macam faktor pembatas. Peningkatan produksi tanaman pada tanah gambut dapat dilakukan dengan berbagai alternatif. Beberapa diantaranya adalah dengan penambahan unsur hara dan teknologi yang tepat dalam budidaya rumput tersebut. Salah satu teknologi yang perlu dilakukan adalah melakukan proses pemupukan terhadap tanaman yang dibudidayakan, salah satunya adalah dengan pemberian kompos.

Keunggulan yang dimiliki kompos

Trichoderma antara lain mudah diaplikasikan, tidak menghasilkan racun atau toksin, ramah lingkungan, tidak mengganggu organisme lain terutama yang berada di dalam tanah serta tidak meninggalkan residu di dalam tanaman maupun tanah (Puspita et al., dalam Amin, 2015). Teknologi pemberian kompos yang didekomposisi dengan jamur Trichoderma sp. sudah banyak dilakukan untuk berbagai tanaman, diantaranya pada tanaman padi sebagai hasil penelitian Elfina et al., (2011) yang menyatakan pertumbuhan vegetatif tanaman yang diberi trichokompos meningkat 2 kali lipat dibanding yang tidak diberi trichokompos,

Hasil penelitian Puspita et al., dalam Rahimah (2015), menyatakan bahwa aplikasi kompos Trichoderma terformulasi dengan dosis $50 \mathrm{gr} /$ ploybag dapat meningkatkan pertumbuhan bibit kelapa sawit. Afitin dan Darmanti (2009) menyatakan dengan aplikasi kompos Trichoderma sp. pada tanaman jagung sebanyak 30 ton $\mathrm{Ha}^{-1}$ memberikan hasil yang optimal terhadap pertumbuhan dan produksi tanaman jagung pada lahan kering.

Tujuan penelitian ini adalah untuk mengetahui pengaruh pemberian kompos Trichoderma terhadap pertumbuhan dan produksi rumput Brachiaria humidicola di lahan gambut dan untuk mengetahui dosis kompos Trichoderma yang memberikan hasil yang terbaik terhadap pertumbuhan dan produksi rumput Brachiaria humidicola di lahan gambut

\section{METODE PENELITIAN}

Penelitian ini dilaksanakan di Desa Tanjung Taruna Kecamatan Jabiren Raya Kabupaten Pulang Pisau pada bulan September sampai dengan bulan November 2018. Bahan yang digunakan antara lain rumput Brachiaria humidicola, kompos Trichoderma, kapur dolomit dan lahan seluas $\pm 270 \mathrm{~m}^{2}$. Alat yang digunakan adalah, cangkul, garu, parang, pisau, timbangan gantung, timbangan digital, meteran, kamera dan alat tulis-menulis

Penelitian ini dirancang dengan menggunakan Rancangan Acak Lengkap (RAL) dengan perlakuan tunggal berbagai dosis pupuk kompos $(\mathrm{K})$ yaitu :

$$
\begin{aligned}
& \mathrm{k} 0=\text { tanpa pupuk } \\
& \mathrm{k} 1=20 \text { ton ha-1 } \\
& \mathrm{k} 2=30 \text { ton } \mathrm{ha}^{-1} \\
& \mathrm{k} 3=40 \text { ton } \mathrm{ha}^{-1}
\end{aligned}
$$

Masing - masing perlakuan diulang 5 kali sehingga terdapat 20 satuan percobaan. Data yang didapatkan dilakukan analisis 
ragam atau uji $\mathrm{F}$ dengan taraf nyata $5 \%$ dan $1 \%$. Bila terdapat perbedaan nyata antar perlakuan yang dicobakan selanjutnya dilakukan uji DMRT (Duncan Multiple Range Test) pada taraf 5\%.

\section{HASIL DAN PEMBAHASAN}

\section{Jumlah Anakan}

Berdasarkan hasil analisis ragam pada 2 minggu, 4 minggu, 6 minggu dan 8 minggu setelah penanaman, jumlah anakan menunjukkan hasil yang tidak nyata antar perlakuan yang dicobakan pada semua umur pengamatan (2 minggu, 4 minggu, 6 minggu dan 8 minggu setelah tanam).

Hal ini diduga pemberian kompos masih belum mampu meningkatkan jumlah anakan pada masa pertumbuhan vegetatif tanaman. Unsur hara yang terdapat dalam kompos maupun dalam tanah belum cukup dan berimbang untuk meningkatkan jumlah anakan rumput Brahiaria humidicola sehingga pemberian dosis kompos trichoderma mempunyai pengaruh yang sama terhadap jumlah anakan.

\section{Tinggi Tanaman}

Hasil analisis ragam terhadap tinggi tanaman menunjukkan bahwa perlakuan kompos memberikan pengaruh yang nyata terhadap tinggi vertikal rumput Brahiaria hunidicola pada umur 6 mst dan memberikan pengaruh yang sangat nyata pada umur $8 \mathrm{mst}$, tetapi tidak berpengaruh pada umur $2 \mathrm{mst}$ dan 4 mst.

Tabel 1. Rata-rata pengaruh dosis kompos terhadap tinggi tanaman rumput Brahiaria humidicola umur $6 \mathrm{smt}$ dan $8 \mathrm{mst}$

\begin{tabular}{llr}
\hline \multirow{2}{*}{ Dosis Kompos } & \multicolumn{2}{c}{ Tinggi Tanaman } \\
\cline { 2 - 3 } & $6 \mathrm{mst}$ & $8 \mathrm{mst}$ \\
\hline k0 $($ Kontrol $)$ & $59,00^{\mathrm{a}}$ & $94,50^{\mathrm{a}}$ \\
$\mathrm{k} 1 \quad\left(20\right.$ ton $\left.\mathrm{ha}^{-1}\right)$ & $69,30^{\mathrm{b}}$ & $112,65^{\mathrm{b}}$ \\
$\mathrm{k} 2 \quad\left(30\right.$ ton ha $\left.^{-1}\right)$ & $75,15^{\mathrm{c}}$ & $122,75^{\mathrm{c}}$ \\
$\mathrm{k} 3 \quad\left(40\right.$ ton $\left.\mathrm{ha}^{-1}\right)$ & $69,90^{\mathrm{b}}$ & $113,05^{\mathrm{b}}$ \\
\hline
\end{tabular}

Keterangan : Rata-rata pada kolom yang diikuti huruf yang sama menunjukkan tidak berbeda nyata berdasarkan Uji DMRT pada taraf $\alpha 0,05$

Pada umur pengamatan 2 mst terhadap variabel tinggi tanaman menunjukkan tidak berbeda nyata. Hal ini mengindikasikan bahwa pemberian dosis kompos tersebut memberikan efek yang sama pada tiap perlakuan pada umur tanaman $2 \mathrm{mst}$. Selanjutnya pada umur tanaman $4 \mathrm{mst}$, perlakuan k0, k1, k2 dan k3 juga tidak menunjukkan perbedaan yang nyata antar perlakuan yang dicobakan. Pada umur pengamatan 6 mst terlihat bahwa perlakuan kontrol berbeda dengan perlakuan $\mathrm{k} 1, \mathrm{k} 2$ dan $\mathrm{k} 3$, perlakuan $\mathrm{k} 1$ dan $\mathrm{k} 3$ sama, perlakuan k2 berbeda dengan semua perlakuan lainnya.

Pada pengamatan terakhir (8 mst) memperlihatkan kecenderungan yang sama seperti pada umur tanaman 6 mst dimana perlakuan kontrol berbeda dengan perlakuan $\mathrm{k} 1$, k2 dan k3, perlakuan k2 berbeda dengan semua perlakuan k0, k1 dan k2, sedangkan perlakuan k1 dan k3 tidak menunjukan perbedaan.

Pada Tabel 1 terlihat bahwa pemberian dosis kompos pada $2 \mathrm{mst}$ dan $4 \mathrm{mst}$ belum memberikan pengaruh terhadap tinggi tanaman rumput Brahiaria humidicola, hal ini dikarenakan pada masa awal pertumbuhan, tanaman belum dapat menyerap unsur hara secara maksimal sehingga pemberian dosis kompos tersebut memberikan efek yang sama pada tiap perlakuan pada umur tanaman 2 mst dan 4 mst.

Pada pengamatan tinggi tanaman umur 6 mst dan 8 mst terlihat kecenderungan yang sama dimana semakin banyak dosis kompos yang diberikan sampai dengan dosis 40 ton ha 
-1, maka tinggi tanaman akan cenderung semakin bertambah, hal ini menunjukkan pemberian kompos mampu menyediakan unsur hara bagi tanaman sehingga mampu membantu proses laju fotosintesis yang pada akhirnya dapat memacu pertumbuhan tinggi tanaman.

Sejalan dengan pendapat Nasution (2009), yang menyatakan bahwa tanaman akan dapat tumbuh subur apabila unsur hara dalam keadaan tersedia dalam tanah, karena pertumbuhan tanaman tergantung dari unsur hara yang diperoleh dari tanah serta dipengaruhi oleh penambahan unsur hara yang diperoleh dari pemberian kompos.

Berdasarkan hasil pengamatan pada Tabel 1 hasil uji lanjut menjelaskan bahwa pemberian kompos cenderung meningkatkan tinggi tanaman. Tanaman terpendek didapatkan jika tanaman tidak diberi kompos sedangkan tanaman yang paling tinggi didapatkan pada pemberian dosis kompos 30 ton $\mathrm{ha}^{-1}$. Kurang optimalnya pertumbuhan tinggi tanaman yang tidak diberi kompos adalah karena ketersediaan unsur hara yang rendah di dalam tanah sehingga proses perpanjangan dan pembelahan sel pada ujung tanaman tidak optimal. Semakin tinggi dosis kompos yang diberikan terhadap tanaman memperlihatkan pertambahan tinggi yang lebih baik.

Hal ini sejalan dengan pendapat Marsono (2001), pengaruh kompos dengan dosis tinggi pada penggunaannya akan menyediakan unsur hara yang diperlukan bagi tanaman misalnya unsur hara makro $(\mathrm{N}$, $\mathrm{P}$ dan K). Bahan organik pada kompos dapat mengikat unsur hara yang mudah hilang dan menyediakannya bagi tanaman.

Pertambahan tinggi tanaman berkaitan erat dengan unsur hara makro salah satunya adalah unsur Nitrogen. Berdasarkan hasil uji Laboratorium terhadap kompos terlihat bahwa kandungan Nitrogen (N) kompos cukup tinggi dibandingkan dengan pupuk kandang kotoran sapi. Unsur Nitrogen dibutuhkan tanaman untuk pembentukan klorofil dan protein. Menurut Rafi (2013) unsur Nitrogen berfungsi sebagai penyusun dari banyak senyawa esensial bagi tumbuhan, misalnya asam-asam amino. Semakin banyak unsur hara Nitrogen yang diserap tanaman akan meningkatkan pertumbuhan dan perkembangan tanaman.

Pemberian kompos Trichoderma dapat meningkatkan ketersediaan hara terutama unsur Nitrogen pada tanah sehingga dapat memacu pertumbuhan tinggi tanaman. Karena kebutuhan Nitrogen dapat tercukupi maka pertambahan tinggi tanaman yang diberi kompos menjadi semakin maksimal.

Menurut Rosita et al. (2007) yang menyatakan bahwa pertumbuhan tanaman semakin meningkat dengan bertambahnya umur tanaman. Meningkatnya pertumbuhan tanaman ini diduga karena adanya penambahan unsur hara dengan penambahan bahan organik.

Disamping itu terdapat pula kecenderungan pada variabel tinggi tanaman, dimana pada dosis 40 ton ha $^{-1}$ tinggi tanaman semakin menurun, hal ini diduga terjadi karena penambahan dosis bahan organik yang terdapat dalam kompos trichoderma terlalu banyak sehingga terjadi konsumsi mewah pada tanah, peningkatan dosis kompos tidak diikuti dengan peningkatan pertumbuhan, tanaman akan menyerap kompos lebih banyak daripada yang diperlukan untuk hasil maksimal sehingga akan berpengaruh negatif pada pertumbuhan tanaman. Buckman dan Brady (1974) dalam Kusnadi (2006) menyatakan bahwa hambatan yang terjadi karena meningkatnya populasi mikroba aktif sehingga jumlah $\mathrm{CO}_{2}$ yang ada dalam tanah juga bertambah sedangkan jumlah $\mathrm{O}_{2}$ berkurang yang mengakibatkan pertumbuhan tinggi tanaman terhambat.

\section{Produksi Tanaman}

Hasil sidik ragam terhadap produksi tanaman berupa bobot basah tanaman, menunjukkan bahwa perlakuan kompos memberikan pengaruh yang sangat nyata terhadap produksi tanaman rumput Brahiaria humidicola. 
Tabel 2. Rata-rata pengaruh dosis kompos terhadap produksi tanaman rumput Brahiaria humidicola $\left(\right.$ ton $\mathrm{ha}^{-1}$ )

\begin{tabular}{llc}
\hline \multicolumn{2}{l}{ Dosis Kompos } & Produksi/Bobot Basah (ton ha $\left.{ }^{-1}\right)$ \\
\hline k0 & $($ Kontrol $)$ & $2,91^{\mathrm{a}}$ \\
k1 & $\left(20\right.$ ton ha $\left.{ }^{-1}\right)$ & $9,75^{\mathrm{b}}$ \\
k2 & $\left(30\right.$ ton $\left.^{-1}\right)$ & $12,87^{\mathrm{c}}$ \\
k3 & $\left(40\right.$ ton ha $\left.\mathrm{ha}^{-1}\right)$ & $12,24^{\mathrm{c}}$ \\
\hline
\end{tabular}

Keterangan : Rata-rata pada kolom yang diikuti huruf yang sama menunjukkan tidak berbeda nyata berdasarkan Uji DMRT pada taraf $\alpha 0,05$

Tabel 2 memperlihatkan bahwa pada perlakuan kontrol berbeda dengan perlakuan $\mathrm{k} 1$, k2 dan $\mathrm{k} 3$, demikian pula dengan perlakuan $\mathrm{k} 1$ juga berbeda dengan $\mathrm{k} 2$ dan $\mathrm{k} 3$, sedangkan perlakuan k2 dan k3 menunjukkan pengaruh yang sama, namun pada perlakuan $\mathrm{k} 2$ dengan dosis 30 ton $\mathrm{ha}^{-1}$ menunjukkan rata-rata produksi tertinggi sebesar 12,87 ton $\mathrm{ha}^{-1}$. Dalam penelitian ini berdasarkan hasil uji lanjut terlihat bahwa pada dosis 30 ton ha $^{-1}$ sudah cukup mampu meningkatkan produksi bobot basah tanaman.

Pengaruh kompos trichoderma terhadap bobot basah tanaman secara keseluruhan menunjukkan bobot basah tanaman kontrol lebih rendah dibandingkan perlakuan lainnya. Bobot basah menunjukkan kemampuan tanaman dalam menyerap bahan organik yang digunakan untuk proses pertumbuhan tanaman. Hal ini juga berkaitan dengan peran akar dalam menyerap unsur hara yang disediakan kompos.

Pertumbuhan dan perkembangan tanaman memerlukan unsur hara dan air, penyerapan air dan hara yang baik diperngaruhi oleh pertumbuhan akar, dengan pemberian kompos trichoderma maka pertumbuhan akar menjadi lebih baik sehingga proses penyerapan hara dan air berjalan baik yang berakibat juga terhadap pertumbuhan dan perkembangan tanaman akan lebih baik. Kompos Trichoderma selain mengandung bahan organik yang diperlukan untuk pertumbuhan, juga mengandung jamur Trichoderma dimana jamur tersebut mampu mengeluarkan senyawa antifungi sehingga zat tersebut merupakan penghalang bagi masuknya jamur pathogen tular tanah. Dilaporkan bahwa Trichoderma harzianum mengeluarkan zat aktif semacam hormon auksin yang merangsang pembentukan akar lateral (Suwahyono, 2004)

Disamping itu pemberian kompos memberikan pengaruh yang positif pada kesuburan tanah, hal ini dapat terjadi oleh adanya perbaikan sifat fisik, kimia dan biologi tanah. Perbaikan sifat fisik, kimia dan biologi tanah dengan penambahan bahan organik dapat memberikan dukungan bagi media yang berfungsi sebagai pensuplai air, oksigen dan hara bagi tanaman. Hal ini sejalan dengan pendapat Eriawan dan Yanto (2009) bahwa peningkatan bahan organik seperti kompos akan berpengaruh terhadap keadaan fisik, kimia dan biologi tanah. Dilaporkan oleh Sutedjo dan Kartasapoetra (2004) meningkatnya kandungan bahan organik pada tanah dapat menurunkan tingkat erodibilitas tanah karena bahan organik dapat mengikat dan mempertahankan kemantapan struktur tanah.

Sejalan dengan pendapat Suriadikarta (2005) yang menyatakan bahwa. sumbangan bahan organik terhadap pertumbuhan tanaman bermula dari pengaruhnya terhadap sifat fisik, kimia dan biologi tanah. Bahan organik berperan sebagai penambah unsur hara $\mathrm{N}, \mathrm{P}$ dan $\mathrm{K}$ bagi tanaman dari hasil mineralisasi mikroorganisme

Tanaman dapat tumbuh dan berkembang dengan sempurna jika tanaman mendapatkan unsur hara dalam jumlah yang tepat. Terlebih lagi tanah yang digunakan dalam penelitian ini adalah tanah gambut. 
Berdasarkan hasil analisis tanah awal terlihat bahwa unsur hara $\mathrm{N}, \mathrm{P}$ dan $\mathrm{K}$ serta $\mathrm{pH}$ nya sangat rendah, sehingga perlu penambahan dari luar untuk menunjang pertumbuhan tanaman.

Ditambahkan dengan pendapat Sarief (1985) dalam Aberar et al. (2011), bahwa peningkatan unsur hara seperti $\mathrm{N}, \mathrm{P}$ dan $\mathrm{K}$, dimana unsur $\mathrm{N}$ berfungsi untuk pembentukan bagian vegetatif seperti daun, batang dan akar, juga membuat klorofil yang terbentuk semakin meningkat dan mempercepat sintesis karbohidrat diubah menjadi protein. Klorofil sendiri berfungsi penting dalam proses fotosintesis tanaman, bila proses fotosintesis berlangsung dengan baik maka hasil fotosintesis akan semakin meningkat yang kemudian ditranslokasikan ke bagian vegetatif tanaman yang nantinya akan mendukung pertumbuhan dan perkembangan tanaman.

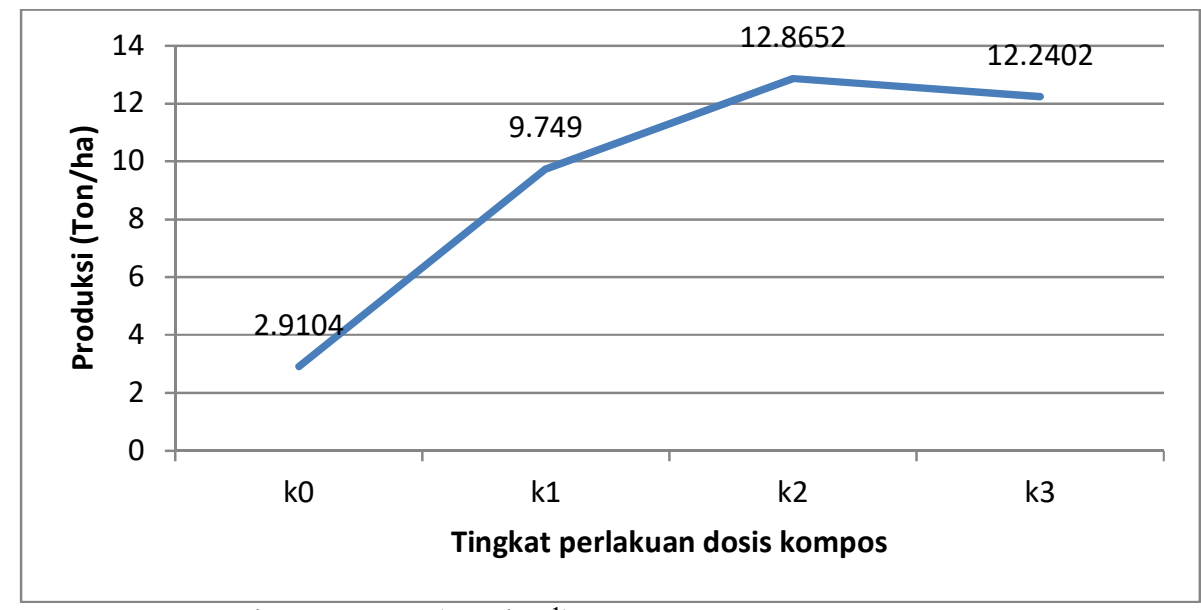

Dosis Kompos (ton ha-1)

Gambar 1. Produksi tanaman rumput Brahiaria humidicola pada berbagai tingkat perlakuan dosis kompos

Dari gambar 1 terlihat pemberian kompos dengan dosis 30 ton ha ${ }^{-1}(\mathrm{k} 2)$ merupakan hasil yang terbaik dibandingkan dengan dosis 40 ton ha ${ }^{-1}(\mathrm{k} 3), 20$ ton $\mathrm{ha}^{-1}(\mathrm{k} 1)$ dan tanpa pemberian kompos atau kontrol (k0). Hal ini menunjukkan semakin tingginya dosis kompos yang diberikan sampai batas tertentu dapat meningkatkan kandungan unsur hara sehingga perakaran dalam tanah mampu berkembang dengan baik kemudian dapat meningkatkan pertumbuhan dan meningkatkan bobot basah tanaman. Tanaman dapat tumbuh dan berkembang dengan sempurna jika tanaman mendapatkan unsur hara dalam jumlah yang tepat. Hal ini sejalan dengan pendapat Nurahmi (2010) yaitu penambahan unsur hara sesuai dengan kebutuhan maka dapat meningkatkan produksi namun apabila melebihi maka dapat menghambat pertumbuhan dan perkembangan tanaman.

Dalam penelitian ini berdasarkan hasil uji lanjut terlihat bahwa pada dosis 30 ton ha ${ }^{-1}$ sudah cukup mampu meningkatkan produksi bobot segar tanaman atau dengan kata lain unsur hara terutama unsur hara $\mathrm{N}$ di dalam tanah telah mencukupi untuk mendukung pertumbuhan dan produksi tanaman. Sebaliknya tanaman tidak akan tumbuh baik bila unsur hara $\mathrm{N}$ tidak tercukupi pada tanaman. Pernyataan ini diperkuat oleh Purwanti (2009), bahwa kekurangan unsur hara $\mathrm{N}$ menyebabkan tanaman tumbuh kerdil dan pertumbuhanya tersendat, hal ini 
ditunjukkan pada perlakuan kontrol (k0) dimana produksi berat segarnya paling rendah dibandingkan produksi tanaman yang diberikan perlakuan dosis lebih besar

Pada dosis 40 ton $\mathrm{ha}^{-1}$ dibandingkan dengan dosis 30 ton $\mathrm{ha}^{-1}$ tidak menunjukkan peningkatan pada produksi tanaman. Hal ini menunjukkan bahwa batas optimal pemberian kompos untuk mendapatkan produksi yang maksimal adalah 30 ton $\mathrm{ha}^{-1}$. Pada dosis tersebut pemberian kompos sudah mencapai tingkat optimum untuk dapat dimanfaatkan tanaman. Tanaman mengambil unsur hara hanya sampai batas tertentu sesuai kebutuhannya, bila terdapat berlebih maka tidak akan diabsorbsi oleh tanaman.

Dikuatkan dengan pendapat Novizan (2004) pemberian dosis pupuk harus tepat karena terdapat fenomena "Peningkatan hasil yang menurun". Fenomena tersebut berarti pemberian pupuk harus diberikan pada dosis yang tepat karena produktivitas tanaman dapat mencapai maksimal dengan pemberian pupuk pada dosis tertentu. Penambahan pupuk tidak akan berpengaruh pada peningkatan produktivitas bahkan menambah biaya produksi sehingga pendapatan menurun.

\section{KESIMPULAN DAN SARAN}

\section{Kesimpulan}

1. Pemberian kompos memberikan pengaruh terhadap tinggi tanaman rumput Brahiaria humidicola umur 6 mst dan 8 mst serta produksi tanaman.

2. Pemberian dosis kompos 30 ton $\mathrm{ha}^{-1}$ memberikan pengaruh yang terbaik terhadap produksi rumput Brahiaria humidicola.

\section{Saran}

Berdasarkan hasil penelitian dapat disarankan untuk penanaman rumput Brahiaria humidicola di lahan gambut menggunakan kompos Trichoderma dengan dosis 30 ton ha ${ }^{-1}$

\section{DAFTAR PUSTAKA}

Aberar, M., A. Mursyid, G.M.S. Noor. 2011. Pengaruh Pemberian Beberapa Dosis Pupuk Trichokompos dengan Interval Waktu Pemberian Terhadap Pertumbuhan, Serangan Hama Penyakit dan Hasil pada Tanaman Tomat ( Lycopersicum esculentum Mill) Di Lahan Sulfat Masam. Fakultas Pertanian Universitas Lambung Mangkurat. Banjarbaru.

Afitin, R dan Darmanti. 2009. Pengaruh Dosis Kompos dengan Stimulator Trichoderma Terhadap Pertumbuhan dan Produksi Tanaman Jagung (Zea mays L.) Varietas Pioner-11 pada Lahan Kering. Jurnal Bioma. Universitas Diponegoro.

Amin, F., Adiwirman dan Sri Yosefa. 2015. Studi Waktu Aplikasi Pupuk Kompos Leguminosa Dengan Bioaktivator Trichoderma sp. Terhadap Pertumbuhan dan Produksi Tanaman Cabai Merah (Capsicum annum L.) Jorn Faperta Vol 2. Universitas Riau

Elfina, Y., A Arsyad, Agus Salim, Jefri Efendi dan Efita Rahmi. 2001. Penggunaan Agens Hayati Trichoderma local Riau Sebagai Biofertilizer dan Biopestisida Dalam PHT untuk Mengendalikan Penyakit dan meningkatkan Produksi Padi. Laporan Penelitian. Universitas Riau dan Litbang Pertanian.

Eriawan, B dan Yanto.S. 2009. Peran Bahan Organik Terhadap Tanah. http;//pupuk npk organiklengkap /peranan-bahanorganik-terhadap-tanah.html. (Diakses tanggal 28 Oktober 2018)

Kusnadi. 2006. Efektifitas Pemberian Dosis Pupuk Hijau Lamtorogung dan $\mathrm{KCl}$ Terhadap Pertumbuhan dan Hasil Ubi 
Jalar (Ipomoea batatas L). Fakultas Pertanian. Universitas Lambung Mangkurat. Banjarbaru.

Marsono dan Sigit P. 2001. Pupuk Akar, Jenis dan Aplikasi. Penebar Swadaya. Jakarta.

Nasution, E. 2009. Aplikasi Beberapa Tandan Kosong Kelapa Sawit Terhadap Pertumbuhan Bibit Jarak Pagar (Jathropa curcas). Fakultas Pertanian. Universitas Riau. Pekanbaru.

Nurahmi, E., Susanna dan Rina S. 2011. Pengaruh Trichoderma terhadap Perkecambahan dan pertumbuhan Bibit Kakao, Tomat dan Kedelai. Jurnal Floratek Unsyiah Banda Aceh.

Novizan. 2002. Petunjuk Pemupukan Yang Efektif. Agromedia Pustaka. Jakarta.

Purwanti, A., Anas D.S. 2009. Pengaruh Jenis Pupuk Organik Terhadap Pertumbuhan dan Produksi Tanaman Sayuran Dalam Nethouse. Makalah Seminar Departemen Agronomi dan Holtikultura Fakultas Pertanian Institut Pertanian Bogor.

Rahimah, M., Mardhiansyah dan Defri Yoza. 2015. Pemanfaatan Kompos Berbahan Baku Ampas Tebu (Saccharum sp.) Dengan Bioaktivator Trichoderma spp. Sebagai Media
Tumbuh Semai. Jurnal Faperta Vol.2 No.1 Februari 2015. Universitas Riau.

Rafi. 2013. Pengaruh Pemberian Kompos Tinja Terhadap Pertumbuhan dan Produksi Tanaman Kedelai (Glycine max (L) merril). Fakultas Pertanian. Universitas Riau.

Rosita. S. M. D. O. Rostiana dan W. Haryudin. 2006. Respon Kencur (Kaempferia Galanga Linn) Terhadap Pemupukan . Prosiding Seminar Nasional dan Pemeran Tumbuhan obat Indonesia XXVII

Suriadikarta, D.A., T. Prihatini, D. Setyorini dan W Hartatik. 2005. Teknologi Pengelolaan Bahan Organik Tanah. Puslitbangtanah. Badan Litbang Pertanian

Sutedjo, M.M dan A.G. Kartasapoetra. 2004. Pengantar Ilmu Tanah Terbentuknya Tanah dan Tanah Pertanian. Rineka Cipta. Jakarta.

Suwahyono, U. dan P. Wahyudi. 2004. Penggunaan Biofungisida pada Usaha Perkebunan.http://www.iptek.net.id/in d/terapan/terapan idx.php?doc $=$ artikel 12. (Diakses tanggal 20 November 2018) 